\title{
Grænser for samling?
}

For et årstid siden kom min søn sjældent hjem uden lommerne fulde af småsten. Nu er han tre år, og enhver gåtur resulterer i, at han har de små næver fast knyttet om pinde og store blades stilke. Disse ting bliver samlet op og siden samlet i adskilte bunker inden døre. Mit ukyndige voksne blik har kun med ringe held formået at afdække, efter hvilke kriterier en genstand samles op eller ej. Hvad sten angår, synes karakteristiske farver dog at spille en vis rolle (hvilket også gælder plastikdimser af enhver slags); med hensyn til pinde er størrelse ikke uvæsentlig. Der er tale om anvendte samlinger i den forstand, at sten igen og igen lægges på række og ind i modelbilers bagagerum, mens pinde bliver til sværd og skjolde, når hjemmet skal forsvares mod drager og tigre. Jeg glæder mig over, at ambitionen for min søn ikke synes at være komplette samlinger af diverse træsorter og stenarter. Men, er der overhovedet tale om samlinger her? Ja, på den måde, at interessen er koncentreret om bestemte typer af naturskabte objekter; de bliver udvalgt blandt mange andre mulige og indgår i en kulturel organisering på drengens værelse. Og alligevel nej, da man kan hævde, at disse ophobninger tilhører kategorierne bunker, stakke og an-dre delmængder. Sådanne opstår formentlig alle steder med menneskelig beboelse.

Min veninde samler på nakkemærker fra herreskjorter, hun gemmer alle dem, hun kan få fat på, også dubletter. Kriteriet er netop mængde. De enkelte mærker registreres ikke efter firmanavn, type, årstal eller andet. Den eksisterende bunke af skjortemærker har aldrig været tænkt som samling; den er en ikke-ordnet delmængde, der med tiden vil kunne genopstå i en ny form, eventuelt ved at mærkerne syes sammen til et billede, når der er mange nok. Den stak Information'er og Weekendaviser, der kan være truende nær ved at vokse nogle af os over hovedet, er også blot en stak, som man helt bestemt vil læse en dag, man får bedre tid, og derefter kassere. Stakken ved siden af med udklip af artikler om, lad os sige den danske folkeskole eller WA's bogtillæg, måske lige fra man blev abonnent, har man derimod tænkt sig at gemme. Og har man de fleste numre, kan stakken transformeres til en samling.

Blandt egentlige samlinger skelner jeg mellem to typer. Den ene er tematiske, hvor målet ikke nødvendigvis er en komplet samling, men hvor samleren har en personlig af-fektion for en bestemt slags ting og samler mange variationer af den. Der vil i sjældne tilfælde være tale om anvendte samlinger, da man næppe bruger alle 700 tekander i det daglige. Til den anden type samlinger hører de mere klassiske, hvor mange mennesker deler samme interesse. Her er komplette samlinger et mål og ofte ét, man må betale dyrt for. Visse genstande som for eksempel frimærker og mønter samles i præfabrikerede albums, hvor de eksemplarer, der kan gøre den aktuelle samling komplet, måske oven i kø-bet er afbilledet. Ekslibris er et andet klassisk samlerobjekt. Det kan gøres tematisk ved at samle på bestemte motiver eller koncentrere sig om én kunstner eller stilart. ,Så bliver det ikke til så mange ekslibris,“ siger en inkarneret samler, ,,men det er lige spændende at finde en ny." I tematiske samlinger, som kun en enkelt eller få personer har, og hvor der derfor ikke er en standard for, hvordan tingene skal ordnes eller registreres, må samleren selv skabe egnet opbevaringsplads. Det kan være reoler til plakater og påklædningsdukker, puder til hattenåle, plancher til uniformsknapper eller mapper til mavebælter.

Samling som investering adskiller sig fra samling som passion. I sidstnævnte tilfælde er det processen i det at opbygge en samling, der er betydningsfuld. Min far har en næsten 
komplet samling af Familie Journalen fra perioden 1877-1947 inklusive alle tillæg (modelkartoner, fotorevyer, håndbøger) og en omfattende tematisk samling om Rødhætte. Den består af billedbøger med nogenlunde samme handlingsforløb, men illustreret af forskellige kunstnere, samt en række meget forskelligartede genstande med Rødhætte som motiv. Han forklarer, at oplevelsen lige såvel består i alt det, han lærer, mens han søger, som i at finde noget, han ikke havde - og som han måske slet ikke vidste fandtes. En samling skal nemlig have en retning! Retningen dirigerer samlerens søgen; den udstikker samlingens grænser og afgør, hvad der er relevant og eftertragtelsesværdigt. For den passionerede samler er det den personlige interesse, der er vigtig, og kvaliteten forringes ikke af, at andre ikke deler den. Er samlingen primært en aldersrente, bør man derimod udvælge sit objekt med omhu og fremsyn, for den monetære værdi af Bjørn Wiinblads 20 juleplatter er jo helt afhængig af antallet af mulige købere. Selv om udgangspunkterne er forskellige, kan den interessebårne samling selvfølgelig godt ende med at måtte opbevares i bankboks.

Endelig skal man ikke forveksle samling som en mængde af genstande og samling som aktivitet. Udenforstående, der ikke deler samlerens passion, kan mene, at der er tale om samlermani, når rum efter rum domineres af bamser eller blikdåser, ølflasker eller æggebægre, modelskibe eller dukkehuse. Bedømmer man udelukkende samling på basis af fysisk fremtoning, har man imidlertid ikke forstået fænomenets hele mening: Ud over glæden ved at eje bestemte genstande - det være sig bryggerietiketter i ubegribeligt antal eller få og sjældne ting i jugendstil - består glæden ved samling i at være i gang med det! Det typiske svar på, hvorfor folk samler på dette eller hint, er, at de bare ikke kan lade være. Med andre ord beror det egentlig ikke på bevidste valg; tilbøjeligheden kan endog være arveligt betinget. Mange har knap nok valgt, hvilke ting de konkret samler på; snarere har enkelte begivenheder medført, at tingene nærmest valgte personen. Denne mekanisme genkender en anden veninde. Oftest er det smukke, gamle møbler og boliginventar, hun falder for. Noget beholder hun en tid og sælger det så videre eller bytter sig til andre ting. Hun præciserer, at hun er samler, men hun opbygger ikke samlinger. Omvendt kan man købe sig til en samling uden at være samler.

Dengang bogstaverne på bilers nummerplader viste, i hvilket amt bilen var hjemmehørende, indsamlede børn den hændelse, at en given bil var kørt forbi, ved at skrive nummerpladens nummer ned. Det gjaldt om at have flere end kammeraterne, og at skrive samme nummer mere end én gang var snyd. En nutidig variant af denne type indsamling, som jeg kalder dokumentarisk, udspiller sig et par gange om ugen i udkanten af Kastrup Lufthavn. Opmærksomheden er rettet mod de russiske fly, der lander og letter. Flytyper og flynumre registreres. Samlerne kender de enkelte maskiners motorer og faciliteter, og det er især spændende, når der kommer en maskine, de ikke har set før. En mand foreviger flyafgange og landinger i lyd og levende billeder; andre tager blot faste billeder.

Som andre etnografer holder jeg af kategorier, og jeg har lige startet en indsamling af samlertyper. I løbet af få dage har jeg allerede fået en elleve-tolv karakteristiske måder at omgive sig med ting på. Der er sikkert flere.

For - er der grænser for samling? Tja. Den enkelte samling har grænser. At forestille sig grænser for mulige samlerobjekter er svært. Samling som proces er en aktivitet uden ende. 